\title{
Using a Data-driven Learning Program to Enhance EFL Student Teachers' Psychological Flow
}

\section{Dr. Heba Moustafa Elmansi}

Lecturer at Department of Curriculum \& Instruction (TEFL)

Faculty of Education Damietta University

\section{Abstract}

7 he research aimed at investigating the effect of using a data-driven learning (DDL) program to enhance EFL student teachers' psychological flow. The participants of the study were sixty (60) second year general section student teachers' in Damietta University, Faculty of Education, Egypt. The research adopted the quasi-experimental research design. So, there were two groups: an experimental group $(n=30)$ and a control one $(n=30)$. To collect data, the researcher used a psychological flow scale. The researcher taught the experimental group through using a data-driven learning program while the control group was taught through the regular method of teaching. The results of the research revealed that there was a statistically significant difference between the mean scores of the experimental group and the control group in the psychological flow in favor of the experimental group. The effect size of using a data-driven learning program was found to be high. The research recommends using a DDL program as a technique in enhancing student teachers' psychological flow.

Key Words: Data-driven Learning (DDL), Psychological Flow.

\section{Introduction and background}

The world is now rapidly becoming a smaller multicultural entity where different thoughts, practices, and beliefs are promoted through intercultural exchange. The concept of psychological flow remains difficult to define, despite progress in the body of research surrounding it. The 
construct of psychological flow was defined and articulated within the framework of positive psychology and its validity remains clear today. However, not much research has focused on studying it (Asakawa \& Yana, 2010). It is perhaps for that reason that this psychological phenomenon has still been neither sufficiently defined nor articulated.

Csikszentmihalyi (2008) explained a psychological flow state in terms of functioning, asserting that this construct is mainly an experience in which one's abilities are in balance with the challenges posed by executing a task with clear objectives and norms, and feedback to guide execution. Furthermore, said task must require very intense concentration, in turn altering one's perception of time, and even state of consciousness. The whole process is so enjoyable; meanwhile, that one wants to repeat it even when it holds no external rewards. It is a specific state of consciousness that occurs when cognition, emotions and motivation work in an integrated and interactive way, responding to requests from both the outer and the inner world. In the flow all the psychic energy is invested in the ongoing experience (and thus on the artifacts of culture within that context) and the person experiences a state of competence (resulting from past life), self-determination, meaning and well-being that will lead the person to search the situations, contexts and activities (in other words, artifacts) that allow such positive inner states.

Several approaches have been presented to describe Csikszentmihalyi's psychological flow theory. Csikszentmihalyi (2016) describes nine necessary dimensions in order for an activity to prompt a flow state: 
clear goals; immediate feedback; a match between personal skills and challenges; merge of action and awareness; facilitate concentration on the task,; aid a sense of control; loss of self-consciousness during the task; sense of time changed; and the experience of becoming autotelic. Hoffman and Novak (1996) summarized the dimensions proposed by Csikszentmihalyi into five dimensions: enjoyment; telepresence; focused attention; engagement; and time distortion. Meanwhile, Rodriguez-Sanchez and Schaufeli (2008) stated that the previous dimensions could be simplified into just three key aspects: absorption, enjoyment, and intrinsic interest.

A great number of recent flow studies have centered on virtual (computer-based) engagement though countless contexts for flow theory research exist, ranging from microbiological to national defense applications. On the other hand, instructors and supervisors still misunderstand the essence of the psychological flow in the educational process .Many of them use traditional approaches based on memorization and drilling (Mourtaga, 2010). Therefore, it is necessary to use modern strategies and approaches to keep up with the age of internet, information, technology, globalization and Corona-Virus. Data-driven learning can offer valuable insights for many of the psychological flow dimensions. This type of learning can increase the students' motivation and interest in learning English, and consequently increase students' psychological flow.

This research is one of the first conducted in this field, however, the research scope is to provide a framework to lead students to flow, highlighting the importance of 
identifying if the data- driven learning is capable of leading students to flow, as well, to associate the flow experience with the student's learning.

\section{Literature Review and Related Studies \\ Nature of Psychological Flow}

The notion of flow state was introduced by Csikszentmihalyi (1975) as a technical term to describe a good feeling or -optimal experiencell that people have as a motivating factor in their daily activities, such as at work, sports, and artistic performance. It is a psychologically optimal state from three points of view: from the cognitive perspective as there is the possibility of understanding; from the emotional perspective as there is the possibility of positive emotions; from the motivational perspective as there is the possibility of engagement (Faiola et al. 2013). According to this author, the key to understanding flow state is the autotelic experience concept (from the ancient Greek $\alpha v^{\prime} \tau \tau \tau \varepsilon \lambda \dot{\eta} \varsigma$, or -self-goal). Autotelic experience is the result of an activity or situation that produces its own intrinsic motivation, rewards, or incentives, specifically without any outside goals or rewards.

\section{Measuring Psychological Flow Experience}

There are three common ways to measure flow experiences: the flow questionnaire (FQ), the experience sampling method (ESM), and the standardized scales of the componential approach (Moneta, 2012).

\section{Flow questionnaire (FQ)}

The FQ requires individuals to identify definitions of flow and situations in which they believe that they have 
experienced flow, followed by a section that asks them to evaluate their personal experiences in these flow-inducing situations. The FQ identifies flow as multiple constructs, therefore allowing the results to be used to estimate differences in the likelihood of experiencing flow across a variety of factors.

\section{Experience sampling method (ESM)}

The ESM requires individuals to fill out the experience sampling form (ESF) at eight randomly chosen time intervals throughout the day. The purpose of this is to understand subjective experiences by estimating the time intervals that individuals spend in specific states during everyday life. The ESF is made up of 13 categorical items and 29 scaled items. The purpose of the categorical items is to determine the context and motivational aspects of the current actions (these items include: time, location, companionship/desire for companionship, activity being performed, and reason for performing activity).

\section{Standardized scales}

Some researchers are not satisfied with the methods mentioned above and have set out to create their own scales. The scales developed by Jackson and Eklund are the most commonly used in research, mainly because they are still consistent with Csíkszentmihályi's definition of flow and consider flow as being both a state and a trait. Jackson and Eklund created two scales that have been proven to be psychometrically valid and reliable: the Flow State Scale-2 (which measures flow as a state) and the Dispositional 
Flow Scale-2 (designed to measure flow as either a general trait or domain-specific trait).

\section{Psychological Flow Dimensions}

The Flow scales were theoretically grounded in Csikszentmihalyi's (2016) nine - dimensional conceptualization of flow. These nine dimensions are: challenge-skill balance, action-awareness merging, clear goals, unambiguous feedback, concentration on task, sense of control, loss of self-consciousness, time transformation, and autotelic experience (Nakamura and Csíkszentmihályi, 2009 \& Wright, 2012).

D1. Balance between challenge and skills: people perceive the situation as challenging and stimulating, and perceive that their resources are balanced and are adequate to the situation. D2. Union between conscience and action: people feel totally involved in the action: automatisms permit the person to provide a more fluid performance, without neither the perception of intrusive thoughts nor the perception of effort. D3. Clear goals: clear, defined and measurable objectives derive from coherent and noncontradictive information. This increases motivation and gives meaning to the experience. D4. Immediate and direct feedback: during the activity people receive punctual and clear feedback from the situation, so that they are able to monitor steadily how they're doing with their task. D5. Focus on task: attention is solely focused on the current task and there's no space for any unnecessary information. D6. Sense of control: people have the perception of a 
spontaneous and automatic control. D7. Loss of selfconsciousness: people perceive to be part of the task they are performing. Psychological energy is fully focused on action and people feel free to act and careless of other's judgment. Furthermore, the feeling that one's limits can be overcome increases the feeling of perceived self-efficacy. D8. Transformation of time: the perception of the flow of time is altered: in some cases it feels faster, in others it is perceived as slowed down. And D9, autotelic experience: this dimension concern the intrinsic satisfaction that the person feels in carrying out the task, regardless of the expected results and of the other possible motivation to act. Subjective satisfaction emerges from the execution of the task, without any need for an external reward.

\section{Effects of Psychological Flow on Language Learning Outcomes}

Shernoff \& Csikszentmihalyi (2008:132) asserted that the theory of flow is "inherently related to learning". Rogatko (2007) pinpoints a triad of research trends in educational flow: studies of correlations between flow characteristics and activities, studies of potential factors influencing flow, and studies of flow's effect on performance or personal affect.

Flow Theory's focus on matching the skill level with the challenge level but ensuring that it's just out of reach, is similar to Vygotsky's Zone of Proximal Development (ZPD) of the socio-cultural approaches (e.g., Lantolf, 2006). This "growth-enhancing" aspect of flow theory has been researched extensively in psychology (Asakawa, 
2004: 125). The zone of actual development ZAD refers to the task that a child can do alone and unassisted. When a teacher assigns a task and the students are able to do it, the task is within the ZAD. They have already been taught and have mastered the skills involved in that task. McLeod (2012) illustrated the idea of ZPD which is the difference between what learners can do without help and what they can do under the guidance of adult or in cooperation with a more experienced person.

In the proposed model of the relationship between flow and language acquisition, Joy Egbert hypothesized that a language learning task involving the following six conditions is most probable to evoke state of flow (Egbert, 2003: 502): The challenge is appropriate and the goals are clear, the task is interesting, sufficient time is allotted, feedback is immediate, learners have control, learners have a chance to focus with lack of interruptions.

\section{Studies Related to Psychological Flow}

The following studies illustrate the benefits of designing activities to lead students to the psychological flow state. These studies include (Dos Santos et al, 2018 ; Dos Santos et al, 2017; Amini et al, 2016; Hong et al, 2013; Elias et al, 2010; Pearce, 2004; Egbert, 2003 ). These studies declared the importance of improving students' psychological flow. Therefore, the present research focused on developing student teachers' psychological flow through using the DDL approach.

This research focused on DDL approach to enhance student teachers' psychological flow. According to the 
findings, the conditions under which the participants experienced flow during activities fit the flow state models. The researcher observed the student teachers as they attempted to learn according to flow principles. When learners were deeply interested in the lexical activities to write correct sentences, they were immersed in the activity and the occurrence of flow state promoted successful language development. Finding flow is clearly a good way of finding enjoyment, happiness, enhancing motivation, control, concentration, attention, absorption and engagement in different types of second language learning.

\section{Nature of Data-driven Learning (DDL)}

DDL is a methodology that applies corpora to language teaching and learning. Smart (2014: 187) characterized DDL as "an approach that provides a structured, scaffold framework for inductive learning". The notion of "Data Driven Learning (DDL)" was first introduced by Johns (1990) to describe how language learners themselves could explore the language and discover some rules and regularities for themselves. Hence, language learners are viewed as detectives. The main characteristic of this approach is that the learners themselves have an active role in teasing out the grammatical patterns for themselves after they have been exposed to samples of authentic language (Elmansi et al, 2021)

\section{Characteristics of DDL}

There is a big difference data-driven language learning and traditional teaching mode. Its characteristics can be 
summarized in four aspects (Cheong, 2013; CampoyCubillo et al., 2010).

First, DDL centers on learner autonomy. It emphasizes the students' autonomic learning, in which activities in the class are student-centered rather than led by the teacher to give full play to their personal characteristics. Second, it uses authentic, rich massive corpora as the main language input. Corpus-based data-driven learning provides students with high quality, vast amounts of language data from real communicative activities. In a word, data-driven learning can create an authentic language environment for students to improve their language intuition to practice their ability to deal with language variation, in order to help them acquire authentic language. Third, it emphasizes the exploration and discovery of learning process. Students learn through problem-solving activities rather than being instructed directly by the teacher. Data-driven learning provides students with a lot of real data based on corpus, to guide students to observe the learning process according to their own needs to experience, explore, and discover the knowledge of language. As a result, the language knowledge that students acquire will be more authentic and systemic, and the impression will be deeper. Finally, it advocates bottom-up, inductive learning. Not in the datadriven learning, students first come into contact with a large amount of authentic language data, but not prescriptive grammatical rules. After their independent observations, they will generalize grammatical rules. With concordance software, students can easily obtain a list of 
contextualized examples of the investigated feature when dealing with tasks such as the acquisition of grammatical structures and lexical items.

\section{Types of Data-driven Learning}

DDL is not viewed in a purely discovery-based approach to learning as originally proposed by Johns (1991). Instead, many researchers (Boulton, 2010; Basanta \& Martin, 2007; Clifton \& Phillips, 2006; Hadley, 2002) acknowledge the usefulness of teacher-guided searches of known rules with other corpus features. The pedagogical applications of the use of corpus have been categorized into direct and indirect applications (Flowerdew, 2012).

Indirect applications include those applications that have indirect effects on teaching and learning materials introduced by researchers and material designers. Direct applications, on the other hand, refer to those applications that involve both teacher-corpus interaction and learnercorpus interaction. In the last few years, this direct interaction with the corpus tools has been coined DataDriven Learning (DDL) referring to "the use in the classroom of computer generated concordances to get students to explore the regularities of patterning in the target language, and the development of activities and exercises based on concordance output." This call to implement the DDL approach in education has been the foundation of a new era of learning in terms of pedagogical methods, curriculum design, and assessment over the last two decades (Champers, 2005). Therefore, The researcher 
designed a program depended on paper-based DDL through using printed concordances to find the patterns and computer-based DDL through using computer generated concordances to get students to explore the regularities of patterning in the target language through different activities to enhance student teachers' psychological flow.

\section{Studies Related to Data-Driven Learning Approach}

The effect of DDL is tackled from a variety of perspectives including errors correction, enhancement of fluency, complexity and particular tasks of language skills. The majority of the empirical studies that have been conducted on issues of DDL and language skills agreed that the DDL approach has positive effects on the overall improvement of language skills. There are many studies that declared the effectiveness of using DDL approach with different language skills such as (Elmansi et al 2021; Mao et al 2018; Luo 2016; Vyatkina, 2016; Mizumoto \& Chujo, 2016; Ucar \& Yükselir, 2015; Yunus \& Awab, 2014). These studies declared the importance of using DDL approach in enhancing students' language skills. Therefore, the present research focused on developing student teachers' psychological flow through using the DDL approach.

\section{Statement of the Problem}

In light of the previous literature review and the researcher's experience in teaching student teachers, the problem of the research is that EFL student teachers' have low psychological flow skills while engaging in doing lexico-grammatical performance skills in EFL writing 
activities. Therefore, the present research is an attempt to solve this problem through using data-driven learning and testing its effectiveness in improving EFL student teachers' psychological flow.

\section{Research Questions}

The present research attempted to answer the following main question:

"How can a data-driven learning program contribute to enhance second year general section student teachers' psychological flow?"

\section{The main question leads to the following sub questions:}

- What are the psychological flow skills required for the second year general section student teachers at the faculty of Education?

- What are the features of the proposed data-driven learning program?

- To what extent can a data-driven learning program enhance second year general section student teachers' psychological flow?

\section{Purpose of the Research}

The present research aims at

- Investigating the impact of using a data-driven learning program in improving the psychological flow dimensions of the second year general section student teachers.

- Raising students' and researchers' awareness of using innovative methods in teaching to improve psychological flow skills. 


\section{Significance of the Research}

The significance of this research comes through these points:

- Helping specialists in organizing an effective teaching learning environment through using data-driven learning approach.

- Helping syllabus designers to modify, organize, and enrich English language curricula with activities based on applying data-driven learning.

- Providing English language syllabus designers with more information and techniques about psychological flow dimensions.

- Providing a teacher guide of how to teach by using computer based on DDL and paper based on DDL to apply Hybrid Learning to improve psychological flow.

\section{Participants of the Research}

A group of 60 second year general section student teachers were purposively selected from Damietta University, Faculty of Education, English department in New-Damietta in the academic year 2020/2021. The study targeted selected participants that have computer and internet skills. Students' age ranged from 20 to 21 years old. The participants of this research constituted a homogeneous group in terms of their schooling and English language proficiency. This number of participants was divided equally into two groups. The first group of 30 students comprised the experimental group and received a data-driven learning program. The other group of 30 
students served as the control group and received the regular teaching methods course.

\section{Design of the Research}

The design adopted in this research is quasiexperimental design (pretest-posttest). Two groups participated in this research. The first group represented as the experimental group and the second group represented as the control group. The researcher taught the experimental group through using a data-driven learning program while the control group was taught through the regular method of teaching.

\section{Hypotheses of the Research}

The research aimed at testing the following hypotheses:

- There is no statistically significant difference between the mean score of the experimental group and that of the control group in the pre administration of the psychological flow scale.

- There is a statistically significant difference at $\leq(0.05)$ level between the mean score of experimental group and that of control group on the post administration of the psychological flow scale in favor of the experimental group.

- There is a statistically significant difference at $\leq(0.05)$ level between the mean score of students of experimental group on the pre and post administration of the psychological flow scale in favor of the post administration. 
- Using DDL achieves effect size at $(\leq 0.14)$ level for improving student teachers' psychological flow skills.

\section{Instruments and materials of the research}

The researcher made use of the following instruments and materials that designed by the researcher:

- A Data-driven Learning Program

- A Computer and Internet Skills Questionnaire (CISQ)

- The Psychological Flow Scale

\section{Delimitations of the Research}

The current research was delimited to:

- Second year general section student teachers in Damietta University, Faculty of Education, English department in the academic year 2020/2021. The participants were chosen by a Computer and Internet Skills Questionnaire.

- A limited duration for implementing a data- driven learning program (A university semester, i.e., nearly 2 months).

- Fourteen sessions designed by the researcher according to a data-driven learning program.

- Some psychological flow skills required for second year general section student teachers.

\section{Results of the Research}

The first hypothesis stated that "There is no statistically significant difference between the mean score of the experimental group and that of the control group in the pre administration of the psychological flow scale".

The researcher used Independent samples t-test to verify this hypothesis. The results are shown in table (1): 
Table 1: Establishing Homogeneity of the Two Groups on the Psychological Flow Scale

\begin{tabular}{|c|c|c|c|c|c|c|}
\hline \multirow[t]{2}{*}{ Dimensions } & \multirow[t]{2}{*}{ Study groups } & \multirow[t]{2}{*}{ Mean } & \multirow[t]{2}{*}{ SD } & \multicolumn{3}{|c|}{ t-test } \\
\hline & & & & $\mathbf{t}$ & DF & P-value \\
\hline \multirow{2}{*}{$\begin{array}{l}\text { Autotelic } \\
\text { Experience }\end{array}$} & Experimental & 4.17 & $\mathbf{0 . 3 8}$ & \multirow[t]{2}{*}{1.74} & \multirow[t]{2}{*}{58} & \multirow[t]{2}{*}{0.088} \\
\hline & Control group & 4.03 & 0.18 & & & \\
\hline \multirow{2}{*}{ Clear Goals } & Experimental & 4.37 & 0.49 & \multirow[t]{2}{*}{1.12} & \multirow[t]{2}{*}{58} & \multirow[t]{2}{*}{0.267} \\
\hline & Control group & 4.23 & 0.43 & & & \\
\hline \multirow{2}{*}{$\begin{array}{c}\text { Challenge-Skill } \\
\text { Balance }\end{array}$} & Experimental & 4.13 & 0.35 & \multirow[t]{2}{*}{1.24} & \multirow[t]{2}{*}{58} & \multirow[t]{2}{*}{0.221} \\
\hline & Control group & 4.30 & 0.65 & & & \\
\hline \multirow{2}{*}{$\begin{array}{c}\text { Concentration on } \\
\text { Task }\end{array}$} & Experimental & 4.00 & 0.00 & \multirow[t]{2}{*}{1.44} & \multirow[t]{2}{*}{58} & \multirow[t]{2}{*}{0.155} \\
\hline & Control group & 4.07 & 0.25 & & & \\
\hline \multirow[t]{2}{*}{ Paradox of Control } & Experimental & 4.10 & 0.31 & \multirow[t]{2}{*}{1.80} & \multirow[t]{2}{*}{58} & \multirow[t]{2}{*}{0.078} \\
\hline & Control group & 4.00 & 0.00 & & & \\
\hline \multirow{2}{*}{$\begin{array}{c}\text { Unambiguous } \\
\text { Feedback }\end{array}$} & Experimental & 4.20 & 0.41 & \multirow[t]{2}{*}{0.28} & \multirow[t]{2}{*}{58} & \multirow[t]{2}{*}{0.779} \\
\hline & Control group & 4.23 & 0.50 & & & \\
\hline \multirow{2}{*}{$\begin{array}{c}\text { Action-Awareness } \\
\text { Merging }\end{array}$} & Experimental & 4.17 & 0.38 & \multirow[t]{2}{*}{0.75} & \multirow[t]{2}{*}{58} & \multirow[t]{2}{*}{0.456} \\
\hline & Control group & 4.10 & 0.31 & & & \\
\hline \multirow{2}{*}{$\begin{array}{c}\text { Transformation of } \\
\text { Time }\end{array}$} & Experimental & 4.67 & 0.48 & \multirow[t]{2}{*}{0.43} & 58 & 0.666 \\
\hline & Control group & 4.73 & 0.69 & & & \\
\hline Loss of Self- & Experimental & 4.53 & 0.51 & 1.57 & 58 & 0.121 \\
\hline Consciousness & Control group & 4.83 & 0.91 & & & \\
\hline Psychological flow & Experimental & 38.33 & 1.15 & 0.65 & 58 & 0.518 \\
\hline Scale & Control group & 38.53 & 1.22 & & & \\
\hline
\end{tabular}

Note. Table (1) reveals that mean score of the experimental group members were 38.33 and the control group members were 38.53 on the psychological flow scale. It reveals that the mean score of the control group and experimental group were noticeably low in the pre administration of the psychological flow scale. 
The second hypothesis stated that "There is a statistically significant difference at $\leq(0.05)$ level between the mean score of experimental group and that of control group on the psychological flow scale in favor of the experimental group". To verify this hypothesis the " $t$ " test for Independent samples was used. The results are illustrated in table (2):

Table 2: Comparing the Performance of the Two Groups on the Post Administration of the Psychological Flow Scale

\begin{tabular}{|c|c|c|c|c|c|c|}
\hline \multirow[t]{2}{*}{ Scale Dimensions } & \multirow[t]{2}{*}{ Study groups } & \multirow[t]{2}{*}{ Mean } & \multirow[t]{2}{*}{ SD } & \multicolumn{3}{|c|}{ t-test } \\
\hline & & & & $\mathbf{t}$ & DF & P-value \\
\hline \multirow{2}{*}{$\begin{array}{c}\text { Autotelic } \\
\text { Experience }\end{array}$} & Experimental & 18.80 & 1.16 & \multirow[t]{2}{*}{30.25} & \multirow[t]{2}{*}{58} & \multirow[t]{2}{*}{0.001} \\
\hline & Control group & 12.13 & 0.35 & & & \\
\hline \multirow[t]{2}{*}{ Clear Goals } & Experimental & 19.10 & 0.96 & \multirow[t]{2}{*}{29.83} & \multirow[t]{2}{*}{58} & \multirow[t]{2}{*}{0.001} \\
\hline & Control group & 12.53 & 0.73 & & & \\
\hline \multirow{2}{*}{$\begin{array}{c}\text { Challenge-Skill } \\
\text { Balance }\end{array}$} & Experimental & 18.93 & 1.23 & \multirow[t]{2}{*}{27.09} & \multirow[t]{2}{*}{58} & \multirow[t]{2}{*}{0.001} \\
\hline & Control group & 12.30 & 0.53 & & & \\
\hline \multirow{2}{*}{$\begin{array}{c}\text { Concentration on } \\
\text { Task }\end{array}$} & Experimental & 19.17 & 1.02 & \multirow[t]{2}{*}{37.00} & \multirow[t]{2}{*}{58} & \multirow[t]{2}{*}{0.001} \\
\hline & Control group & 12.07 & 0.25 & & & \\
\hline \multirow{2}{*}{$\begin{array}{c}\text { Paradox of } \\
\text { Control }\end{array}$} & Experimental & 19.37 & 0.72 & \multirow[t]{2}{*}{43.83} & \multirow[t]{2}{*}{58} & \multirow[t]{2}{*}{0.001} \\
\hline & Control group & 12.27 & 0.52 & & & \\
\hline \multirow{2}{*}{$\begin{array}{l}\text { Unambiguous } \\
\text { Feedback }\end{array}$} & Experimental & 18.70 & 1.24 & \multirow[t]{2}{*}{27.81} & \multirow[t]{2}{*}{58} & \multirow[t]{2}{*}{0.001} \\
\hline & Control group & 12.10 & 0.40 & & & \\
\hline \multirow{2}{*}{$\begin{array}{l}\text { Action- } \\
\text { Awareness } \\
\text { Merging }\end{array}$} & Experimental & 19.20 & 1.03 & \multirow[t]{2}{*}{31.75} & \multirow[t]{2}{*}{58} & \multirow[t]{2}{*}{0.001} \\
\hline & Control group & 12.30 & 0.60 & & & \\
\hline \multirow{2}{*}{$\begin{array}{c}\text { Transformation } \\
\text { of Time }\end{array}$} & Experimental & 19.30 & 0.88 & \multirow[t]{2}{*}{29.16} & 58 & 0.001 \\
\hline & Control group & 12.77 & 0.86 & & & \\
\hline Loss of Self- & Experimental & 19.13 & 0.90 & 39.78 & 58 & 0.001 \\
\hline $\mathrm{Cl}$ & Control group & 12.13 & 0.35 & & & \\
\hline Psychological & Experimental & 171.70 & 2.82 & 105.20 & 58 & 0.001 \\
\hline & Control group & 110.60 & 1.48 & & & \\
\hline
\end{tabular}


Note. As table (2) reveals the mean score of the experimental group students on the post administration of the scale were noticeably high and statistically significant compared with their own mean scores on the pre administration of the same scale. The " $t$ " values of the dimensions ranged between (43.83-27.09), all of which are statistically significant at (0.001).

The mean scores of the experimental group students in the post administration of the whole scale were (171.70) compared to that of the control group (110.60). The value of " $\mathrm{t}$ " of the scale as a whole was (105.20). This indicates that the program based on DDL was effective in enhancing the participants' psychological flow.

The third hypothesis stated that "There is a statistically significant difference at $\leq(0.05)$ level between the mean score of students of experimental group on the pre and post administration of the psychological flow in favor of the post administration". To test this hypothesis, the researcher used Paired samples t-test. The results are shown in the table (3):

Note. Results in table (3) show that the experimental group performance in the post administration of the psychological flow scale was better than that of the preadministration. The mean score on the post one was (171.70) compared to (38.33) in the pre administration. These differences were significant at $(0.001)$ for the whole individual dimensions and the total scale score.

The fourth hypothesis stated that "Using DDL achieves effect size at $(\leq 0.14)$ level for improving student teachers' psychological flow". 
Table 3: Comparing the Experimental Group Performance on the Pre and Post Administration of the Psychological Flow

\begin{tabular}{|c|c|c|c|c|c|c|}
\hline \multirow{2}{*}{$\begin{array}{c}\text { Psychological Flow } \\
\text { Dimensions }\end{array}$} & \multirow[t]{2}{*}{ Test } & \multirow[t]{2}{*}{ Mean } & \multirow[t]{2}{*}{ SD } & \multicolumn{3}{|c|}{ t-test } \\
\hline & & & & $\mathbf{t}$ & $\mathbf{D F}$ & P-value \\
\hline \multirow[t]{2}{*}{ Autotelic Experience } & $\begin{array}{l}\text { Pre- } \\
\text { test }\end{array}$ & 4.17 & 0.38 & \multirow[t]{2}{*}{69.14} & \multirow[t]{2}{*}{29} & \multirow[t]{2}{*}{0.001} \\
\hline & $\begin{array}{c}\text { Post- } \\
\text { test }\end{array}$ & 18.80 & 1.16 & & & \\
\hline \multirow[t]{2}{*}{ Clear Goals } & $\begin{array}{c}\text { Pre- } \\
\text { test }\end{array}$ & 4.37 & 0.49 & \multirow[t]{2}{*}{68.83} & \multirow[t]{2}{*}{29} & \multirow[t]{2}{*}{0.001} \\
\hline & $\begin{array}{c}\text { Post- } \\
\text { test }\end{array}$ & 19.10 & 0.96 & & & \\
\hline \multirow[t]{2}{*}{ Challenge-Skill Balance } & $\begin{array}{c}\text { Pre- } \\
\text { test }\end{array}$ & 4.13 & 0.35 & \multirow[t]{2}{*}{63.81} & \multirow[t]{2}{*}{29} & \multirow[t]{2}{*}{0.001} \\
\hline & $\begin{array}{c}\text { Post- } \\
\text { test }\end{array}$ & 18.93 & 1.23 & & & \\
\hline \multirow[t]{2}{*}{ Concentration on Task } & $\begin{array}{c}\text { Pre- } \\
\text { test }\end{array}$ & 4.00 & $\mathbf{0 . 0 0}$ & \multirow[t]{2}{*}{81.45} & \multirow[t]{2}{*}{29} & \multirow[t]{2}{*}{0.001} \\
\hline & $\begin{array}{c}\text { Post- } \\
\text { test }\end{array}$ & 19.17 & 1.02 & & & \\
\hline \multirow[t]{2}{*}{ Paradox of Control } & $\begin{array}{c}\text { Pre- } \\
\text { test }\end{array}$ & 4.10 & 0.31 & \multirow[t]{2}{*}{113.05} & \multirow[t]{2}{*}{29} & \multirow[t]{2}{*}{0.001} \\
\hline & $\begin{array}{c}\text { Post- } \\
\text { test }\end{array}$ & $\mathbf{1 9 . 3 7}$ & 0.72 & & & \\
\hline \multirow[t]{2}{*}{ Unambiguous Feedback } & $\begin{array}{c}\text { Pre- } \\
\text { test }\end{array}$ & 4.20 & 0.41 & \multirow[t]{2}{*}{$\mathbf{5 5 . 4 5}$} & \multirow[t]{2}{*}{29} & \multirow[t]{2}{*}{0.001} \\
\hline & $\begin{array}{c}\text { Post- } \\
\text { test }\end{array}$ & 18.70 & 1.24 & & & \\
\hline \multirow[t]{2}{*}{$\begin{array}{c}\text { Action-Awareness } \\
\text { Merging }\end{array}$} & $\begin{array}{c}\text { Pre- } \\
\text { test }\end{array}$ & 4.17 & 0.38 & \multirow[t]{2}{*}{74.99} & \multirow[t]{2}{*}{29} & \multirow[t]{2}{*}{0.001} \\
\hline & $\begin{array}{c}\text { Post- } \\
\text { test }\end{array}$ & 19.20 & $\mathbf{1 . 0 3}$ & & & \\
\hline \multirow[t]{2}{*}{ Transformation of Time } & $\begin{array}{c}\text { Pre- } \\
\text { test }\end{array}$ & 4.67 & 0.48 & \multirow[t]{2}{*}{75.17} & 29 & 0.001 \\
\hline & $\begin{array}{c}\text { Post- } \\
\text { test }\end{array}$ & 19.30 & $\mathbf{0 . 8 8}$ & & & \\
\hline Loss of Self-Consciousness & $\begin{array}{c}\text { Pre- } \\
\text { test }\end{array}$ & 4.53 & 0.51 & 82.57 & 29 & 0.001 \\
\hline & $\begin{array}{c}\text { Post- } \\
\text { test }\end{array}$ & $\mathbf{1 9 . 1 3}$ & 0.90 & & & \\
\hline Psychological flow Scale & $\begin{array}{c}\text { Pre- } \\
\text { test }\end{array}$ & 38.33 & 1.15 & 226.75 & 29 & 0.001 \\
\hline & $\begin{array}{c}\text { Post- } \\
\text { test }\end{array}$ & 171.70 & 2.82 & & & \\
\hline
\end{tabular}


To calculate the effect size of the independent variable (teaching using a program based on DDL) on the dependent variable (psychological flow), the $(\eta 2)$ value was calculated as presented in table (4):

Table 4 :

The Effect Size of Using a Program Based on DDL on the Experimental Group Psychological Flow

\begin{tabular}{|c|c|c|c|c|}
\hline $\begin{array}{c}\text { Dependent } \\
\text { Variables }\end{array}$ & T & DF & $\begin{array}{c}\text { Eta square } \\
\left(\eta^{2}\right)\end{array}$ & Effect size \\
\hline $\begin{array}{c}\text { Psychological } \\
\text { flow }\end{array}$ & 226.75 & 29 & 0.999 & Large \\
\hline
\end{tabular}

Note. Results in table (4) indicate that the effect size ( $\eta 2)$ of the program based on DDL on the psychological flow was arranged respectively (0.992-0.995-0.988-0.999). This illustrates the effectiveness of using a program based on DDL in improving the experimental group student teachers' psychological flow. Figure (1) shows size effect of using a program based on DDL in improving the experimental group student teachers' psychological flow improvement.

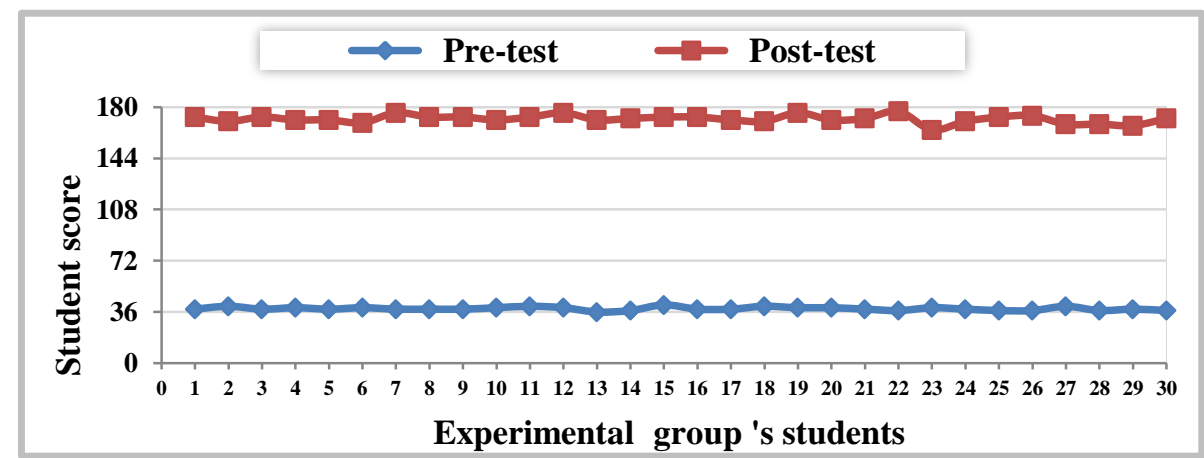

Figure 1

The Effect Size of Using a Program Based on DDL on Students' Psychological Flow Improvement 


\section{Discussion of the Research Results}

The results revealed that most of the participants evidently had a positive attitude towards the DDL approach as it is considered to be a useful resource to achieve psychological flow state. In particular, almost all of the participants thought that their psychological flow state was enhanced by applying the program through the DDL approach as it helped them understand the lesson and be able to apply activities to achieve psychological flow state.

The research revealed that DDL can be an effective tool to improve students' psychological flow because learners take an active role in working through an extensive language material independently which consolidates their anatomy. Exposure to authentic language input make learners more sensitive towards language variation. In addition, discovery learning is enhanced because using data-driven is an inquiry-based activity and opposes explicit instruction by the teacher.

Results of the current research are in line with those of (Dos Santos et al, 2018 \& 2017; Amini et al, 2016; Hou, 2015; Hong et al, 2013; Elias et al, 2010; Pearce, 2004 \& Egbert, 2003) asserted the importance of developing learners' psychological flow through using different approaches and strategies. This research, however, is a pioneer in using DDL to improve students' psychological flow.

During the implementation of the DDL program the researcher noticed that the results of the current research indicated the verification of the previous hypothesis and 
the high value of the experimental treatment's effect size upon the overall psychological flow state skills. Some student teachers of the experimental group expressed their positive attitudes towards using a program based on datadriven learning. Students' positive opinions can be summarized in the following points:

- DDL based program improves creativity and selfdiscovery in student teachers.

- DDL provides student teachers' with lots of authentic materials produced by the native speakers.

- The program increases student teachers' consciousness and self-discovery of linguistic rules and patterns.

- DDL gives them the opportunity of enhancing their selfautonomy.

- The program encourages students' independent learning.

In conclusion, this research revealed the higher effect of DDL in teaching psychological flow state than the traditional way. It was effective, because the students did search for the target language and learned by themselves, the students started to become linguistic researchers investigating the real meaning of the target language in a real context. In addition, achieving deep levels of immersion/engagement, enjoyable feelings, concentration, immersion and intensive involvement are the means to improve student teachers psychological flow state.

\section{Conclusions}

A number of conclusions were derived from the current research. 
- Applying DDL helps student teachers to feel more confident to formulate their own findings. It proved suitability for different learners' styles especially kinesthetic. It has a positive effect on student teachers' and sparked their psychological flow through using hands on DDL and hands off DDL.

- Applying DDL approach in learning showed that the more students are exposed to authentic data, the less possibility and the negative transfer occurs as authenticity reduces negative transfer and brings unnatural English to the minimum.

- Using computer based DDL and paper-based DDL approach in teaching gives students a chance to notice and build up rules as it enhances their psychological flow and deepens their understanding.

- The participants also proved that their knowledge of lexical performance skills in EFL writing increased as a result of flow state arousal which was evident in their performance on writing tests.

- DDL program proved that it is more suitable for student teachers level because of the huge amount of data the students need to be exposed to. Hence, it is unsuitable for lower level learners.

\section{References}

- Amini, D., Ayari, S., \& Amini, M. (2016). The Effect of Flow State on EFL Learners"e Vocabulary Learning. International Journal of Multicultural and Multireligious Understanding, 3(5), 9-18.

- Basanta, C., \& Martin, M. (2007). The application of data-driven learning to a small scale corpus: Using filmtranscripts for teaching 
conversational skills. Language and Computers: Studies in Practical Lingusitics, 61, 141-158.

- Boulton, A. (2010). Data-driven learning: On paper, in practice. In T. Harris, \& M. Moreno Jaén (Eds.), Corpus linguistics in language teaching (pp. 17-52). Bern: Peter Lang.

- Campoy-Cubillo, M., Bellés-Fortuno, B. \& Gea-Valor, M. (2010). Corpus-based Approaches to English Language Teaching (Eds.). London: Continuum.

- Chambers, A. (2005). Integrating corpus consultation in language studies. Language Learning \& Technology, 9, 111-125.

- Cheong, E. (2013). Corpus- Informed Research and Learning in ESP: Issues and Applications. English for Specific Purposes 32(3): 190-191. http://doi: 10.1016/j.esp.2013.03.003

- Clifton, J., \& Phillips, D. (2006). Ensuring high surrender value for corporate clients and increasing the authority of the language instructor: The dividends of a data-driven lexical approach to ESP. The Journal of Language for International Business, 17, 7281.

- Csikszentmihalyi, M. (1975). Beyond boredom and anxiety. San Francisco, CA: Jossey- Bass.

- Csikszentmihalyi, M. (2008). Thoughts about education. In D. Dickinson (Ed.), Creating the Flow and the Psychology of Discovery and Invention. New York: Harper Perennial.

- Csikszentmihalyi, M. (2016). 8 ways to create flow according to Mihaly Csikszentmihalyi. Retrieved April 8, 2019, from https:// positivepsychologyprogram.com

- Dos Santos W., Bittencourt, I., Dermeval, D., Isotani, S., Marques, L., \& Silveira, I. (2018). Flow Theory to Promote Learning in Educational Systems: Is it Really Relevant?. Brazilian Journal of Computers in Education (Revista Brasileira de Informática na Educação - RBIE), 26(2), 29-59.

- Dos Santos, W., Gomes, T., \& Silva, C. (2017). Towards to Flow State Identification in Educational Games: An Empirical Study. In Brazilian Symposium on Computers in Education, 28 (1), 927941. http://doi: 10.5753/cbie.sbie

- Egbert, J. (2003). A study of flow theory in the foreign language classroom. The Modern Language Journal, 87, 499-518. 
- Eliasa, H., Mustafa ,S., Roslan , S.,\& Noah.S. (2010). Examining potential relationships between flow and motivational forces in Malaysian secondary school students .Procedia Social and Behavioral Sciences, 9, 2042-2046

- Elmansi, H., Dadour, D., Qoura,A., Hamada, H. (2021). The Impact of Data-driven Learning based Program on Developing Student Teachers' Lexico-grammatical Performance Skills in EFL Writing. Journal of Research in Curriculum Instruction and Educational Technology, 7(3), 37-65. doi: 10.21608/jrciet. 2021. 181573

- Faiola, A., Newlon, C., Pfaff, M., \& Smyslova, O. (2013). Correlating the effects of flow and telepresence in virtual worlds: Enhancing our understanding of user behavior in game-based learning. Computers in Human Behavior, 29(3), 1113-1121.

- Flowerdew, L. (2012). Corpora and language education. Basingstoke, England: Palgrave Macmillan.

- Hadley, G. (2002). An introduction to data-driven learning. RELC Journal, 33, 99-124. http://doi:10.1177/003368820203300205

- Hong, J., Hwang, M., Chen, W., Lee, C., Lin, P., \& Chen, Y. (2013). Comparing the retention and flow experience in playing Solitary and Heart Attack games of San Zi Jing: A perspective of Dual Process Theory. Computers \& Education, 69, 369-376.

- Johns, T. (1990). From printout to handout: Grammar and vocabulary teaching in the context of datadriven learning. CALL Austria, 10, 14-34.

- Luo, Q. (2016). The effects of data-driven learning activities on EFL learners' writing development. Springer Open, 5(1255), 113. https://doi.org/10.1186/s40064-016-2935-5

- Mao, L., Liu, Y. \& Zhang, M. (2018). The Effectiveness of College Student English Writing Teaching Based on Data-Driven Learning. Educational Sciences: Theory \& Practice, 18(5), 11601169. http:// doi.org/10.12738/estp.2018.5.017

- Mizumoto, A., Chujo, K., \& Yokota, K. (2016). Development of a scale to measure learners" perceived preferences and benefits of data-driven learning. ReCALL, 28, 227-246. http://doi:10.1017/ $\underline{\mathrm{S} 0958344015000208}$ 
- Moneta, G. (2012). On the Measurement and Conceptualization of Flow. New York: Springer. ISBN 978-1461423584.

- Mourtaga,K.(2010,October 14-15 ). Poor Writing in English .A case of the Palestinian EFL learners in Gaza Strip [Conference]. First National Conference, Gaza, Palestine. http://scholar.google. com/citations? user=2J2EsiAAAAAJ\&hl=en

- Nakamura, J., \& Csikszentmihalyi, M. (2009). Flow theory and research. In C. R. Snyder \& S. J. Lopez (ed.), Handbook of positive psychology (pp. 25-47). Oxford: Oxford University Press.

- Pearce, J., Ainley, M., \& Howard, S. (2004). The Ebb and Flow of Online Learning. Computers in Human Behavior, 5 (3), 1-32.

- Shernoff, D. \& Csikszentmihalyi, M., (2008). Flow in schools: Cultivating engaged learners and optimal learning environments. In M. Furlong (Ed.), Handbook Of Positive Psychology In Schools (pp. 131-145).

- Smart, J. (2014). The role of guided induction in paper-based data-driven learning. ReCALL, 26, 184-201. http:// doi: 10.1017/ S0958344014000081

- Ucar, S., \& Yükselir, C. (2015). The effect of corpus-based activities on verb-noun collocations in EFL classes. Turkish Online Journal of Educational Technology - TOJET, 14 (2), 195205.

- Vyatkina, N. (2016). Data-driven learning of collocations: learner performance, proficiency, and perceptions. Language Learning \& Technology, 20(3), 159-179.

- Wright, S. (2012). "In the zone": enjoyment, creativity, and the nine elements of "flow". Retrieved May 25, 2019 from http:// www.meaningandhappiness.com

- Yunus, K., \& Awab, S. (2014). The impact of Data-driven learning instruction on Malaysian Law Undergraduates' colligational competence. Kajian Malaysia, 32(1), 79- 109. 